\title{
Estimation of forest Carbon Stocks in Ba Be National Park, Bac Kan province, Vietnam
}

\author{
Nguyen Thi Dong ${ }^{1,}{ }^{*}$, Van Huu Tap ${ }^{1}$, Nguyen Thi Phương Mai ${ }^{1}$, Nguyen Thi Hoang Lien ${ }^{2}$ \\ 1 Faculty of Natural Resources and Environment, TNU - University of Sciences; Thai Nguyen city, Viet Nam; \\ maintp@tnus.edu.vn; tapvh@tnus.edu.vn \\ 2 Faculty of Environmental Science, VNU University of Science, Viennam National Univeristy, Ha Noi, Viet \\ Nam; nguyenthihoanglien@hus.edu.vn \\ * Corresponding author: dongnt@tnus.edu.vn; Tel: 084987264907
}

\begin{abstract}
Climate change and an increase in the greenhouse effect are a matter of global concern. One of reasons for this phenomenon is the increase in greenhouse gases, especially CO2. Therefore, the authors investigated $\mathrm{CO} 2$ absorption from forests of 45 plots in Ba Be National Park, characterized by 3 forest states as rich, medium and poor forest, rehabilitated forest after exploitation to estimate carbon sequestration of the forest. In which, the carbon stock of rich forest reaches 273.17 tones/ha, the medium forest is 136.23 tones/ha and the poor forest, rehabilitated forest is 42.06 tones/ha. With a forest growth rate of $1.8 \%$ per year, the carbon sequestration in Ba Be National Park for 3 forest states is about 16,499 tones per year. This will contribute to improve environmental quality, reducing greenhouse gas emissions and creating a scientific basis for managers to develop a payment mechanism of forest carbon sequestration services.
\end{abstract}

Keywords: Forest carbon; carbon sequestration; natural forest; Ba Be National Park

\section{Introduction}

Recently, a big global problem has been concerned with climate change and the increase in greenhouse effect. This was due to greenhouse gas concentration in the atmosphere, mainly $\mathrm{CO}_{2}$ which contributed for $60 \%$ (UNFCCC, 2007). The $\mathrm{CO}_{2}$ concentration in the atmosphere was recorded at 386 ppm in 2008 (NOAA, 2008). This was the highest level ever recorded for over 800 years (Lüthi et al., 2008). Meanwhile, $\mathrm{CO}_{2}$ in the atmosphere continued to increase (Keeling and Whort, 2002) and reached $414.7 \mathrm{ppm}$ in 2019 (NOAA, 2019). The causes leading to the increase in $\mathrm{CO}_{2}$ concentrations in the atmosphere is the burning of fossil fuels and deforestation in tropical regions (Karsenty, et al., 2002). Forest plays an important role in the global carbon cycle (Dixon et al., 1994), especially, tropical forests have the greatest potential for mitigation of $\mathrm{CO}_{2}$ through conservation and management, (Chaturvedi et al., 2011; Chaturvedi et al., 2015). Carbon sequestration of the forest was investigated by various methods such as destruction method (UN- REDD VietNam, 2012) , non-destruction method (Walker et al., 2015; Chaturvedil., et a 2010), GIS technology and modeling method (Omasa et al., 2003). These methods differ in procedure, complexity and time required, depending on the specific aim of the estimation operation (Gunawardena, 2014).

The destructive method is considered a direct method to estimate carbon stocks. In this method, trees are harvested for determination of the fresh weight from the stem, roots, branches and leaves. After drying the samples in oven at $95-100^{\circ} \mathrm{C}$, to constant weight, dried biomass weight is determined, and the samples are then analyzed by sample incinerator at a temperature of $1000^{\circ} \mathrm{C}$. Since then, various researches have the amount of carbon sequestration from the sample tree and the entire stand. Chave et al (2005) used this method to develop allometric equations for estimating carbon stocks for tropical forests in Africa. Jenkins et al (2004) had compiled more than 1,700 allometric equations for more than 100 species of tree species from 177 samples of trees, mainly estimating biomass based on DBH as predictor (UN-REDD Programe Viet Nam, 2012). Huy \& Tuan 
(2008) developed allometric equations to estimate the carbon sequestration in the evergreen broadleaf forest in the Central Highlands in Viet Nam. In this study, the authors set up an allometric equation using multiple parameters $(\mathrm{BDH}, \mathrm{H}, \mathrm{DW})$ to increase reliability and consider the relationship between them. This method provides reliable but costly results and has many difficulties in sampling and analysis.

Method of modeling and GIS amplification for the forest carbon sequestration has been developing based on estimating a large scale, giving fast results but requiring advanced equipment, technology, and qualifications of human resources (Wilson, 2010; Vu et al., 2014; Abeydeera et al.,2019). Besides, this method has average deviation compared with the destrutive method is $13 \%$ (Green et al., 1997).

In the non-destructive method, the existing data, such as wood density (WD), tree height $(H)$, diameter at breast height (DBH), expansion factor etc., are fitted on available allometric equations to determine the biomass (Huy and Tuan, 2008; Chaturvedi et al.,, 2010; Chaturvedi et al., 2012; Phuong, 2012; Chaturvedi et al.,, 2013; Chaturvedi et al.,, 2015) used this method to estimate biomass and biomass change in tropical forest, and the values could be used for the estimation carbon sequestration through the conversion coefficient of IPCC (2006). This method is easy to calculate, gives fast results but moderate reliability, suitable for rapid-assessment in the protected areas such as National Parks, where harvesting trees is prohibited.

Researches on $\mathrm{CO}_{2}$ absorption of the forest will provide a scientific basis for making more accurate predictions about the increasing rate in greenhouse gases and the impacts of global climate change in the future. However, this data varies greatly between localities and different forest types. Therefore, it is necessary to conduct more studies in this field.

In addition, Vietnam is implementing a payment policy for forest environmental services, including service of forest carbon sequestration. However, this service has not been paid due to the lack of scientific basis and financial mechanisms. Therefore, It is necessary to investigate on the forest carbon sequestration as the basis and premise for the implementation of payment policy for forest carbon services in Ba Be national parks and across Viet Nam to provide more scientific basis for Viet Nam and Ba Be national park for implement payment of forest environment services. The result of investigation will help in establishing a reference level of carbon stock. The information will be later useful to compare the increase or decrease of the carbon stock in the Ba Be national park.

The authors used both the destrutive method and the none destrutive method in order to evaluate the forest carbon sequestration in Ba Be National Park with 3 forest states as rich forest, medium forest, and poor, rehabilitated forest. In which, the destructive method was the estimation of the carbon stock for wood trees and the none destrutive method was the estimation of the carbon stock for the shrub and litter

\section{Materials and Methods}

\subsection{Study area}

We conducted our study in Ba Be National Park (Latitudes 22023'10" - 22028'55" N and $105032^{\prime} 50^{\prime \prime}-105041^{\prime} 45^{\prime \prime} \mathrm{E}$ ), which is a precious natural heritage with a unique system of primary limestone forest and natural mountain lake, which is particularly important in Vietnam.

The total natural area of the strictly protected zone of Ba Be National Park is 10,048 ha, within the administrative boundaries of $\mathrm{Ba}$ Be district including the communes of Nam Mau, a part of Khang Ninh, Cao Tri, Cao Thuong, Quang Khe, Hoang Tri, and Nam Cuong commune, Cho Don district (Ba Be National Park Management Board, 2013).

Study tagert: Estimation of the forest carbon stock in Ba Be national park

Study content: Survey on study area, and determining the forest carbon stock for woody tree layer, shrub layer and litter layer of the rich, average and poor, rehabilitated forest in Nam Mau, Quang Khe, and Hoang Tri communes, Ba Be district; Nam Cuong conmmunes, Cho Don distric, Bac Kan province. 


\subsection{Methods}

\subsubsection{Sampling method and plot survey}

Map and GPS were used to identify random sampling at 45 standard plots with $500 \mathrm{~m} 2(20 \mathrm{~m} \mathrm{x}$ $25 \mathrm{~m}$ ) in 3 forest states as rich forest, ,medium forest and poor, rehabilitated forest in Nam Mau commune (total 15 sample plots, including each 5 sample plots for the rich forest, the average forest and the poor, rehabilitated forest), Quang Khe commune (15 sample plots, including 10 sample plots in medium forest and 5 sample plots in the poor, rehabilitated forest ), Hoang Tri (10 sample plots in medium forest) Ba Be district, and Nam Cuong commune (5 sample plots in the poor, rehabilitated forest), Cho Don district, Bac Kan province to determine woody tree layer carbon stock. A secondary plot of $1 \mathrm{~m} 2$ was established in each plot to investigate shruband litter carbon stock.

\subsubsection{Carbon measurement method:}

- For the woody tree layer:

The authors recorded the diameter at breast height $(\mathrm{DBH}$, breast height $=1.3$ ) of all trees with a DBH $\geq 6 \mathrm{~cm}$ in all the stand plots. To determine the above ground biomass, we used the allometric equation between DBH and above ground biomass (AGB) of the UN-REDD Vietnam program to calculate the above ground biomass for evergreen broadleaf forests in Northeast Vietnam in 2012.

Formula to calculate standing tree biomass:

$A G B=0.1142 * D^{2.4451}$ (UN-REDD Programe Viet Nam, 2012)

In which: - AGB: is the tree biomass standing on the ground

- D: tree diameter measured at $1.3 \mathrm{~m}$

From individual tree biomass, the authors calculated the total biomass for the entire tree in the sample plot and for the whole research area.

Calculating carbon stock based on forest biomass:

Carbon stock $=$ biomass $* 0.47$ (ton/ha) $($ IPCC, 2006)

This co-efficient is widely used internationally, thus it has been applied in this study for calculation of total carbon in the woody tree layer of the study area.

- For the shrub and litter:

Drying samples: Fresh samples from the field were brought to Lab, they were dried at $950 \mathrm{C}$ to constant weight, weighed and recorded data.

Samples crushing: The dried samples were crushed by a grinder and planetary ball mill until it reached the fine powder size.

Sample analysis: the samples were weighted and put in the sample tray of the Lego CHN2000 carbon analyzer. When the analysis mode was selected, the samples from the tray passed to the combustion chamber. Oxygen was supplied to burn the samples at $900-10000 \mathrm{C}$ and for converting the samples into $\mathrm{CO} 2$. This gas passed through the infrared cell to determine the amount of carbon in the samples. 


\section{Results and Discussion}

\subsection{Current status of forest land use in Ba Be National Park}

The total natural area of the core zone of Ba Be National Park is 10,048 ha. In which, the forested area is $7,724.8$ ha, mainly natural forests (99.6\%), the coverage is $75.6 \%$, the average natural forest accounts for $61.8 \%$ of the forested land. Forests on rocky mountains account for $28.3 \%$ of forested land, the rest are mixed forests, bamboo forests, rehabilitated forests, and poor forests, etc. accounting for $10.0 \%$. Area of the planted forest is 28.1 ha, accounting for $0.4 \%$ of forested land. The area of un-forested land is 1,301.2 ha. Besides, there is agricultural land of 497.9 ha and non-agricultural land of 524.1 ha (Ba Be National Park Management Board, 2013). According to the $\mathrm{Ba}$ Be National Park conservation and development plan by 2020 , the buffer zone will be expanded to 25,309 ha. The expansion of the buffer zone will contribute to reduce the pressure on the core of forest land, supporting people to participate in producing a stable household economy and limiting the exploitation of forest products.

\subsection{Composition and quantity of species}

The authors studied 45 plots in Nam Mau, Quang Khe, Nam Cuong and Hoang Tri communes, which represented 3 status of the rich, medium, and poor, rehabilitated forests. The results showed great variation in the quantity and composition of species in that area. The species richness varied from 4 to 19 species per plot. Tree density ranges from 680 trees/ha to 1,580 plants/ha. (Table 1).

Table 1. Density of trees in plots of Nam Mau, Quang Khe, Hoang Tri and Nam Cuong communes

\begin{tabular}{|c|c|c|c|c|c|c|c|c|c|c|c|c|c|c|}
\hline \multirow{3}{*}{$\begin{array}{l}\begin{array}{c}\text { Type of } \\
\text { forest }\end{array} \\
\text { Standard } \\
\text { plots }\end{array}$} & \multicolumn{4}{|c|}{$\begin{array}{l}\text { Poor and rehabilitated forest } \\
\text { in Nam Mau }\end{array}$} & \multicolumn{5}{|c|}{$\begin{array}{l}\text { Medium forest in Nam Mau } \\
\text { commune }\end{array}$} & \multicolumn{5}{|c|}{ Rich forest in Nam Mau } \\
\hline & 12 & 3 & 4 & 5 & 6 & 7 & 8 & 9 & 10 & 11 & 12 & 13 & 14 & 15 \\
\hline & NM NM & NM & NM & NM & NM & NM & NM & NM & NM & NM & NM & NM & NM & NM \\
\hline $\begin{array}{l}\text { Quantity } \\
\text { trees/ha }\end{array}$ & 960900 & 1040 & 800 & 820 & 1260 & 1580 & 1260 & 1240 & 860 & 740 & 980 & 680 & 800 & 860 \\
\hline $\begin{array}{l}\text { Type of } \\
\text { forest }\end{array}$ & \multicolumn{4}{|c|}{$\begin{array}{l}\text { Poor and rehabilitated forest } \\
\text { in Quang Khe }\end{array}$} & \multicolumn{10}{|c|}{ Medium forest in Quang Khe } \\
\hline Standard & 12 & 3 & 4 & 5 & 6 & 7 & 8 & 9 & $10 \mathrm{QK}$ & 11 & 12 & 13 & 14 & 15 \\
\hline plots & QK QK & QK & QK & QK & QK & QK & QK & QK & & QK & QK & QK & QK & QK \\
\hline $\begin{array}{l}\text { Quantity } \\
\text { trees /ha }\end{array}$ & 680960 & 940 & 760 & 1020 & 1000 & 1060 & 860 & 1100 & 820 & 880 & 980 & 1500 & 940 & 1300 \\
\hline $\begin{array}{l}\text { Type of } \\
\text { forest }\end{array}$ & \multicolumn{4}{|c|}{$\begin{array}{l}\text { Poor and rehabilitated forest } \\
\text { in Nam Cuong }\end{array}$} & \multicolumn{10}{|c|}{ Medium forest in Hoang Tri } \\
\hline Standard & $\begin{array}{ll}1 & 2\end{array}$ & 3 & 4 & 5 & 6 & 7 & 8 & 9 & 10 & 11 & 12 & 13 & 14 & 15 \\
\hline plots & $\mathrm{NC} \mathrm{NC}$ & NC & NC & NC & HT & HT & HT & HT & HT & HT & HT & HT & HT & HT \\
\hline Density & 820920 & 1160 & 840 & 1220 & 940 & 1200 & 940 & 780 & 740 & 940 & 840 & 1020 & 1120 & 1240 \\
\hline
\end{tabular}

The result from Table 1 showed that tree density in the medium forest in Nam Mau and Hoang Tri is the highest. This result is suitable for the study of Ekoungoulou et al in Congo (Ekoungoulou et al., 2014). This is explained that the medium forest has the fastest growth speed but the forest has not yet fully closed, so it is suitable for many species to grow. When reaching the old forests, many species cannot be exposed to sunlight, so they die and leading to a decrease in the number of trees at the sample plots. This explains why the number of species in the rich forest area in Nam Mau is low, evenly, the sample plot 12 NM has only 4 species, while in the sample plot 7HT contains 19 species. The average number of trees in the rich forest area, the medium forest, and poor forest 
are about 680, 1126 and 904 trees, respectively.

Species are often concentrated in rich forest areas, including Burretiodendron hsienmu, Markhamia pierrei, Garcinia fragraeoides, Allospondias lakonensis, Chukrasia tabularis, Tetramelet nudiflora, Pterospermum heterophyllum, Fagaceae, etc. While Acanthus ilicifolius L, Jatropha Curcas $L$, etc. The poor and rehabilitated forest areas often focus on Stroblus tonkinensis, S. macrophyllus, Engelhardtia spicata, Machilus, Trema orientalis, T. angustifolia, Senna alata, Oroxylum indicum (L.) Kurz, Alangium chinense, Castanopsis etc are ussualy existed in mdium forest areas.

Diameter classification of trees also varied between the poor forest, medium forest and rich forest. For poor forests, the proportion of trees with diameter at breast height $D 1.3<15 \mathrm{~cm}$ accounted for a large proportion ranging from $60-94 \%$. The proportion of large trees with diameter at breast height D1.3 $>45 \mathrm{~cm}$ accounted for $6.4-20 \%$, concentrated in the rich forest areas in Nam Mau commune. The results were presented in Figure 1, 2, 3. In which, the plot 15NM in the rich forest of Nam Mau has the largest diameter of breast height with $\mathrm{DBH}>45 \mathrm{~cm}$ counting for $27.9 \%$; constantly, the plot $3 \mathrm{NC}$ in the poor, forest in Nam Cuong commune has the smallest DBH, DHB $<15 \mathrm{~cm}$, which it accounts for over $90 \%$.

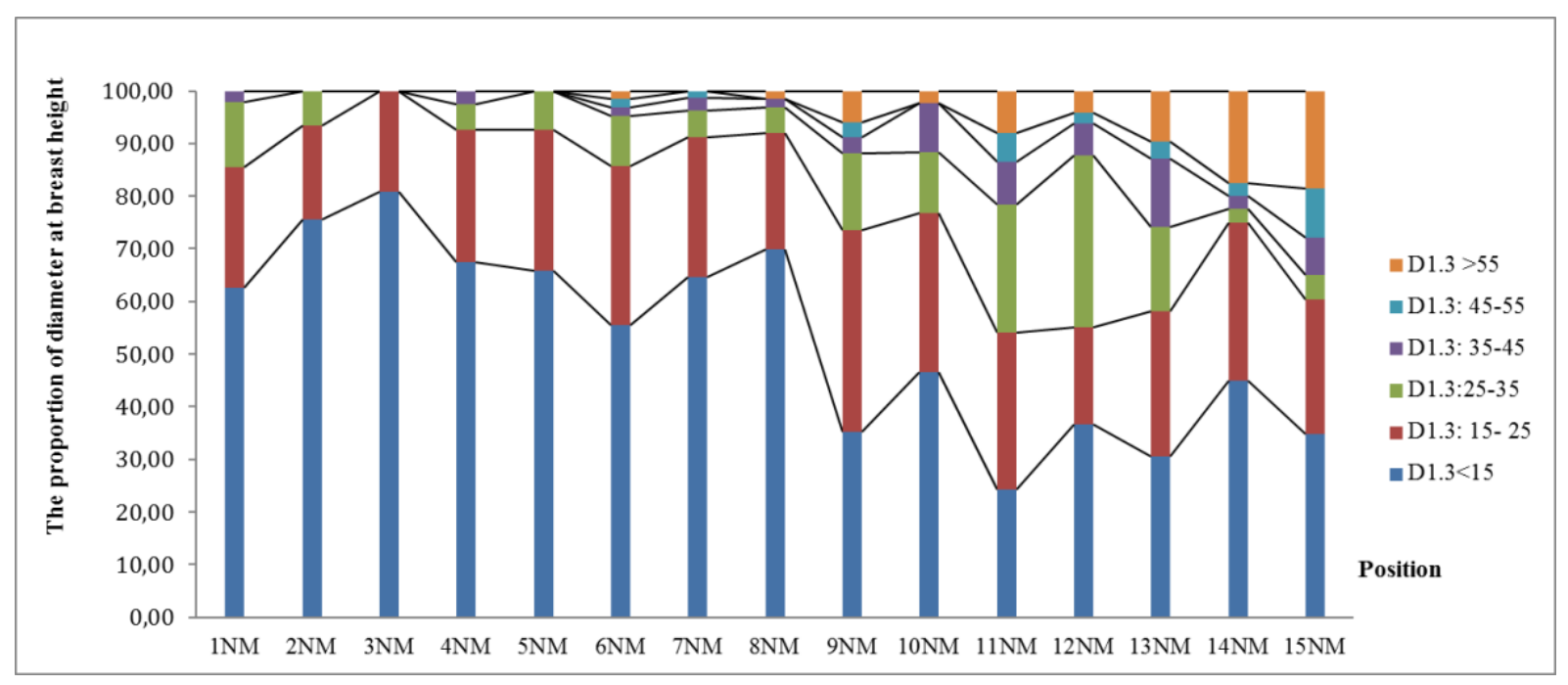

Figure 1. Proportion of tree diameter classification at tstandard plots in Nam Mau commune

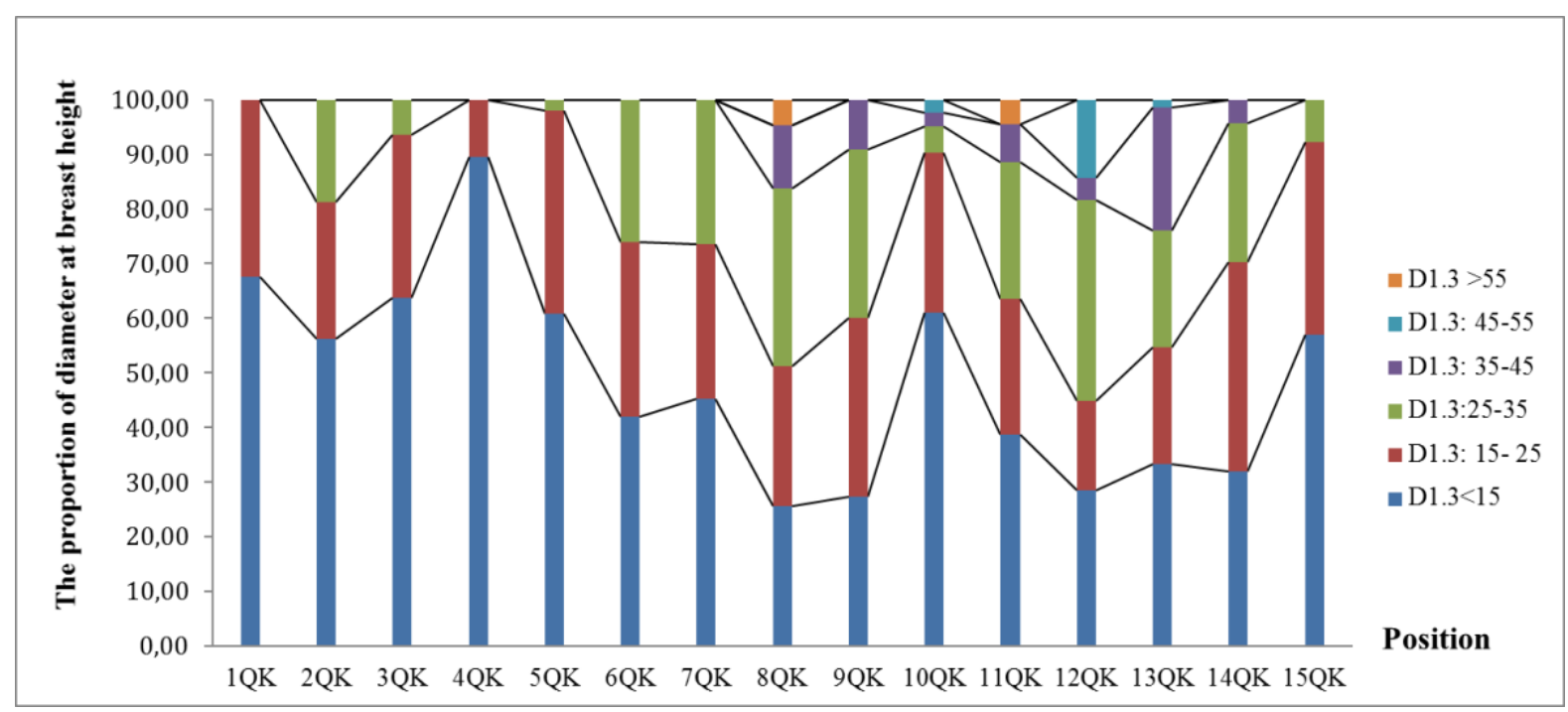

Figure 2. Proportion of tree diameter classification at the standard plots in Quang Khe commune 


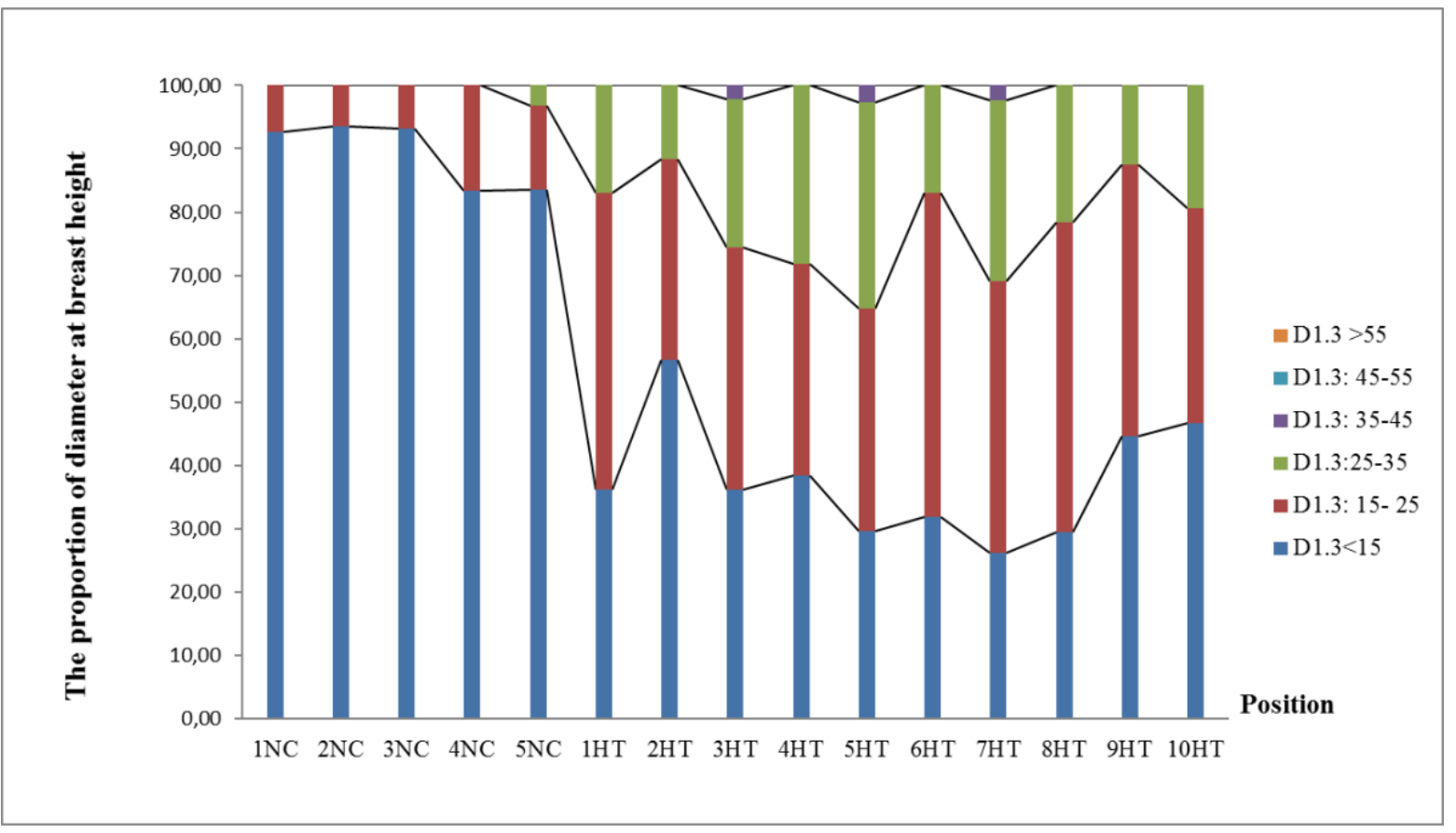

Figure 3. Proportion of tree diameter classification at the standard plots in Nam Cuong, Hoang Tri communes

\subsection{Carbon stock of trees}

Table 5. Above ground Biomass in the standard plot

\begin{tabular}{|c|c|c|c|c|c|c|c|c|c|c|c|c|c|c|c|c|c|c|}
\hline \multirow{2}{*}{ 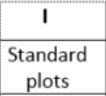 } & \multicolumn{6}{|c|}{ Poor and rehabilitated forest in Nam Mau } & \multicolumn{6}{|c|}{ Medium forest in Nam Mau } & \multicolumn{6}{|c|}{ Rich forest in Nam Mau } \\
\hline & $1 \mathrm{NM}$ & 2NM & 3NM & $4 \mathrm{NM}$ & $5 \mathrm{NM}$ & Average & $6 \mathrm{NM}$ & 7NM & $8 \mathrm{NM}$ & 9NM & $10 \mathrm{NM}$ & Average & $11 \mathrm{NM}$ & $12 \mathrm{NM}$ & $13 \mathrm{NM}$ & $14 \mathrm{NM}$ & $15 \mathrm{NM}$ & Average \\
\hline $\begin{array}{c}\text { AGB } \\
\text { (tones/ha) }\end{array}$ & 130.18 & 69.01 & 55.72 & 93.73 & 74.18 & $\begin{array}{c}84.56 \\
\pm \\
28.92\end{array}$ & 219.36 & 198.40 & 312.03 & 350.10 & 341.14 & $\begin{array}{c}284.20 \\
\pm \\
70.58\end{array}$ & 401.14 & 408.29 & 491.64 & 849.36 & 729.57 & $\begin{array}{c}576.0 \\
\pm \\
202.56\end{array}$ \\
\hline II & \multicolumn{6}{|c|}{ Poor and rehabilitated forest in Quang Khe } & \multicolumn{12}{|c|}{ Medium forest in Quang Khe } \\
\hline $\begin{array}{l}\text { Standard } \\
\text { plots }\end{array}$ & $1 \mathrm{QK}$ & $2 \mathrm{QK}$ & $3 Q K$ & $4 Q \mathrm{QK}$ & $5 Q K$ & Average & $6 Q \mathrm{KK}$ & 7QK & $8 \mathrm{QK}$ & $9 \mathrm{QK}$ & $10 \mathrm{QK}$ & $11 \mathrm{QK}$ & $12 \mathrm{QK}$ & $130 \mathrm{~K}$ & $14 \mathrm{QK}$ & $15 \mathrm{QK}$ & \multicolumn{2}{|c|}{ Average } \\
\hline $\begin{array}{c}\text { AGB } \\
\text { (tones/ha) }\end{array}$ & 54.96 & 137.50 & 98.47 & 38.99 & 94.28 & $\begin{array}{c}84.84 \\
\pm 38.87\end{array}$ & 186.14 & 179.42 & 368.95 & 301.29 & 128.11 & 362.12 & 342.22 & 247.24 & 206.74 & 214.07 & \multicolumn{2}{|c|}{$\begin{array}{c}253.63 \\
\pm \\
84.86\end{array}$} \\
\hline III & & & & & & & \multicolumn{12}{|c|}{ Medium forest in Hoang Tri } \\
\hline $\begin{array}{l}\text { Standard } \\
\text { plots }\end{array}$ & & & & & & & $1 \mathrm{HT}$ & 2HT & 3HT & $4 \mathrm{HT}$ & 5HT & 6HT & 7HT & $8 \mathrm{HT}$ & 9HT & $10 \mathrm{HT}$ & \multicolumn{2}{|c|}{ Average } \\
\hline $\begin{array}{c}\text { AGB } \\
\text { (tones/ha) }\end{array}$ & - & - & - & - & - & - & 150.51 & 154.45 & 191.65 & 148.53 & 177.27 & 169.90 & $\begin{array}{c}187.2 \\
1\end{array}$ & 191.38 & 162.40 & 189.77 & \multicolumn{2}{|c|}{$\begin{array}{c}172.31 \\
\pm \\
17.49\end{array}$} \\
\hline IV & \multicolumn{6}{|c|}{ Poor and rehabilitated forest in Nam Cuong } & & & & & & & & & & & & \\
\hline $\begin{array}{l}\text { Standard } \\
\text { plots }\end{array}$ & 1NC & $2 \mathrm{NC}$ & $3 \mathrm{NC}$ & $4 \mathrm{NC}$ & $5 \mathrm{NC}$ & Average & & & & & & & & & & & & \\
\hline $\begin{array}{c}\text { AGB } \\
\text { (tones/ha) }\end{array}$ & 33.45 & 35.99 & 40.44 & 35.77 & 73.92 & $\mid \begin{array}{c}43.91 \\
\pm \\
16.96\end{array}$ & - & - & - & - & - & - & - & - & - & - & - & - \\
\hline
\end{tabular}

We used the allometric equation for diameter at breast height D1.3 and above ground biomass $(A G B=0.1142 * D 2.4451)$ to determine the above ground biomass of trees at the 45 plots. The results were shown in the figure. In which, the above ground biomass of the rich forest was the biggest with average of 576.0 tones/ha. Especially, at the standard plot $14 \mathrm{NM}$, the above ground biomass reached 849.36 tones/ha. The above ground biomass of the medium forest ranged from 150.5 tones/ha to 368.95 tones/ha, with average of 236.7 tones/ha. The above ground biomass for the poor forest and the rehabilitated forest was the lowest, averaging 71.11 tones/ha. Particularly, at the plot $1 \mathrm{NC}$ the above ground biomass only reached 33.45 tones/ha. As can be seen from the above results that the forest carbon stock of trees in the rich forest areas achieved more than 2.4 
times and 8.1 times compared with the medium forest and the poor, rehabilitated forest, respectively.

From the above ground biomass data, we identified the carbon stock of trees in the study area. The results were shown in table 6 and figure 4.

Table 6. The tree layer carbon stock in the standard plots

\begin{tabular}{|c|c|c|c|c|c|c|c|c|c|c|c|c|c|c|c|c|c|c|}
\hline \multirow{2}{*}{$\begin{array}{c}\text { I } \\
\begin{array}{c}\text { Standard } \\
\text { plots }\end{array}\end{array}$} & \multicolumn{6}{|c|}{ Poor and rehabilitated forest in Nam Mau } & \multicolumn{6}{|c|}{ Medium forest in Nam Mau } & \multicolumn{6}{|c|}{ Rich forest in Nam Mau } \\
\hline & $1 \mathrm{NM}$ & 2NM & 3NM & 4NM & 5NM & TВ & $6 \mathrm{NM}$ & 7NM & 8NM & 9NM & $10 \mathrm{NM}$ & тв & $11 \mathrm{NM}$ & $12 \mathrm{NM}$ & $13 \mathrm{NM}$ & $14 \mathrm{NM}$ & $15 \mathrm{NM}$ & TB \\
\hline $\begin{array}{c}\text { Carbon } \\
\text { stock } \\
\text { (tones/ha) }\end{array}$ & 61.19 & 32.44 & 26.19 & 44.05 & 34.86 & $\begin{array}{c}39.75 \\
\pm \\
13.59 \\
\end{array}$ & 103.10 & 93.25 & 146.65 & 164.55 & 160.34 & $\begin{array}{c}133.58 \\
\pm \\
33.17\end{array}$ & 188.53 & 191.90 & 231.07 & 399.20 & 342.90 & $\begin{array}{c}270.7 \\
\pm \\
90.25\end{array}$ \\
\hline II & \multicolumn{6}{|c|}{ Poor and rehabilitated forest in Quang Khe } & \multicolumn{12}{|c|}{ Medium forest in Quang Khe } \\
\hline $\begin{array}{l}\text { Standard } \\
\text { plots }\end{array}$ & 1QK & $2 \mathrm{QK}$ & 3QK & $4 Q K$ & 5QK & TВ & 6QK & 7QK & $8 Q K$ & 9QK & $10 Q \mathrm{~K}$ & $11 \mathrm{QK}$ & $12 \mathrm{QK}$ & 13QK & $14 \mathrm{QK}$ & $15 Q K$ & \multicolumn{2}{|c|}{ TВ } \\
\hline $\begin{array}{c}\text { Carbon } \\
\text { stock } \\
\text { (tones/ha) }\end{array}$ & 25.83 & 64.63 & 46.28 & 18.32 & 44.31 & $\begin{array}{c}39.88 \\
\pm \\
18.27\end{array}$ & 87.49 & 84.33 & 173.40 & 141.61 & 60.21 & 170.20 & 160.85 & 116.21 & 97.17 & 100.61 & \multicolumn{2}{|c|}{$\begin{array}{c}119.21 \\
\pm \\
39.88\end{array}$} \\
\hline III & & & & & & & \multicolumn{12}{|c|}{ Medium forest in Hoang Tri } \\
\hline $\begin{array}{l}\text { Standard } \\
\text { plots }\end{array}$ & & & & & & & $1 \mathrm{HT}$ & $2 \mathrm{HT}$ & 3нт & $4 \mathrm{HT}$ & $5 \mathrm{HT}$ & $6 \mathrm{HT}$ & 7HT & $8 \mathrm{HT}$ & 9HT & 10HT & \multicolumn{2}{|c|}{ TB } \\
\hline $\begin{array}{c}\text { Carbon } \\
\text { stock } \\
\text { (tones/ha) }\end{array}$ & - & - & - & - & - & - & 70.74 & 72.59 & 90.08 & 69.81 & 83.31 & 79.85 & 87.99 & 89.95 & 76.33 & 89.19 & \multicolumn{2}{|c|}{$\begin{array}{c}80.98 \\
\pm \\
8.22\end{array}$} \\
\hline IV & \multicolumn{18}{|c|}{ Poor and rehabilitated forest in Nam Cuong } \\
\hline $\begin{array}{l}\text { Standard } \\
\text { plots }\end{array}$ & 1NC & 2NC & 3NC & 4NC & $5 N C$ & TB & & & & & & & & & & & & \\
\hline $\begin{array}{c}\text { Carbon } \\
\text { stock } \\
\text { (tones/ha) }\end{array}$ & 15.72 & 16.91 & 19.00 & 16.81 & 34.74 & $\begin{array}{c}20.64 \\
\pm \\
7.97\end{array}$ & - & - & - & - & - & - & - & - & - & - & - & - \\
\hline
\end{tabular}

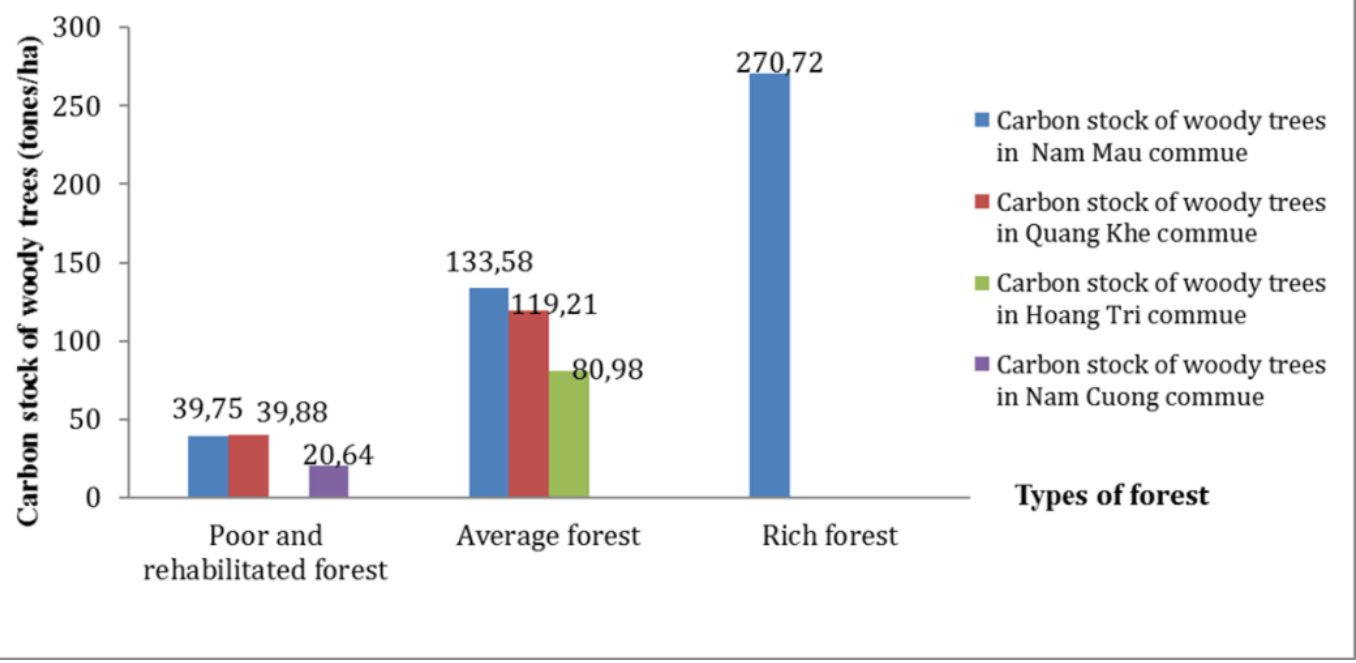

Figure 4. The tree layer carbon stock of types of forests

According to calculated results, the carbon stock of trees increased gradually from the poor, rehabilitated forest to the medium forest and the rich forest accounted for 33.42 tones/ha, 111.26 tones/ha and 270.72 tones/ha, respectively. This data is lower than the above ground carbon stock in the report by Syafinie (2015) in Malaysia with range from 225.55 to 501.74 tones/ha. The difference is due to the geographical area, geological conditions, soil and absorption capacity of different types of forest trees as well as the methods used to estimate the forest carbon sequestration. However, these results are equivalent to forest carbon stock in Bach Ma National Park, Vietnam, which is 267.53 tones/ha for rich forest and 144.16 tones/ha for average forest and poor forest is 37.27 tones/ha (Yen et al., 2016). 


\subsection{Shrub layer and litter layer carbon stock}

Based on the fresh biomass of shrubs and litter was taken from the $1 \mathrm{~m} 2$ second standard plots, the team identified the dry biomass of shrubs and litter. Results were presented in Table 7 and 8. Dry biomass of shrub layer decreased in the rich forest and increased in poor forests: ranging from 0.63 tones/ha to 4.81 tones/ha for Nam Mau commune; 1.0 - 5.45 tones/ha for Quang Khe commune and 0.58 - 3.37 tones/ha for Nam Cuong and Hoang Tri communes.

Table 7. Shrub dry biomass stock in standard plots of communes

\begin{tabular}{|c|c|c|c|c|c|c|c|c|c|c|c|c|c|c|c|c|c|c|}
\hline I & \multicolumn{6}{|c|}{ Poor and rehabilitated forest in Nam Mau } & \multicolumn{6}{|c|}{ Medium forest in Nam Mau } & \multicolumn{6}{|c|}{ Rich forest in Nam Mau } \\
\hline $\begin{array}{l}\text { Standard } \\
\text { plots }\end{array}$ & 1NM & 2NM & 3NM & 4NM & 5NM & Average & $6 \mathrm{NM}$ & 7NM & $8 \mathrm{NM}$ & 9NM & $10 \mathrm{NM}$ & Average & $11 \mathrm{NM}$ & $12 \mathrm{NM}$ & 13NM & $14 \mathrm{NM}$ & $15 \mathrm{NM}$ & Average \\
\hline $\begin{array}{c}\text { Dry } \\
\text { biomass } \\
\text { (tones/ha) }\end{array}$ & 4.41 & 2.25 & 1.52 & 4.38 & 3.91 & $\begin{array}{c}3.29 \\
\pm \\
1.33\end{array}$ & 4.81 & 0.91 & 1.09 & 1.69 & 2.01 & $\begin{array}{c}2.10 \\
\pm \\
1.58\end{array}$ & 1.31 & 0.90 & 1.82 & 0.63 & 1.27 & $\begin{array}{c}1.19 \pm \\
1.54\end{array}$ \\
\hline II & \multicolumn{6}{|c|}{ Poor and rehabilitated forest in Quang Khe } & \multicolumn{12}{|c|}{ Medium forest in Quang Khe } \\
\hline $\begin{array}{l}\text { Standard } \\
\text { plots }\end{array}$ & $1 \mathrm{QK}$ & 2QK & отс & 1QK & $2 \mathrm{QK}$ & Average & 6QK & 7QK & $8 Q K$ & 9QK & 10QK & $11 \mathrm{QK}$ & $12 \mathrm{QK}$ & $13 Q K$ & $14 \mathrm{QK}$ & $15 \mathrm{QK}$ & \multicolumn{2}{|c|}{ Average } \\
\hline $\begin{array}{c}\text { Dry } \\
\text { biomass } \\
\text { (tones/ha) }\end{array}$ & 5.45 & 3.19 & 2.23 & 4.19 & 3.92 & $\begin{array}{c}3.79 \\
\pm \\
1.19\end{array}$ & 1.92 & 1.07 & 2.90 & 1.39 & 1.71 & 1.60 & 1.00 & 1.41 & 1.52 & 2.65 & \multicolumn{2}{|c|}{$\begin{array}{c}1.72 \\
\pm \\
0.69\end{array}$} \\
\hline III & & & & & & & \multicolumn{12}{|c|}{ Medium forest in Hoang Tri } \\
\hline $\begin{array}{l}\text { Standard } \\
\text { plots }\end{array}$ & & & & & & & $1 \mathrm{HT}$ & $2 \mathrm{HT}$ & 3НT & 4HT & 5HT & $6 \mathrm{HT}$ & $7 \mathbf{H T}$ & 8HT & 9HT & $10 \mathrm{HT}$ & \multicolumn{2}{|c|}{ Average } \\
\hline $\begin{array}{c}\text { Dry } \\
\text { biomass } \\
\text { (tones/ha) }\end{array}$ & - & - & - & - & - & - & 1.248 & 0.512 & 0.850 & 1.166 & 0.462 & 0.390 & 1.007 & 1.215 & 0.252 & 1.083 & \multicolumn{2}{|c|}{$\begin{array}{c}0.819 \\
\pm \\
0.375\end{array}$} \\
\hline IV & \multicolumn{6}{|c|}{ Poor and rehabilitated forest in Nam Cuong } & & & & & & & & & & & & \\
\hline $\begin{array}{l}\text { Standard } \\
\text { plots }\end{array}$ & $1 \mathrm{NC}$ & $2 \mathrm{NC}$ & $3 N C$ & $4 \mathrm{NC}$ & $5 \mathrm{NC}$ & Average & & & & & & & & & & & & \\
\hline $\begin{array}{c}\text { Dry } \\
\text { biomass } \\
\text { (tones/ha) }\end{array}$ & 3.17 & 1.53 & 1.46 & 2.29 & 3.37 & $\begin{array}{c}2.37 \\
\pm \\
0.98\end{array}$ & - & - & - & - & - & - & - & - & - & - & - & - \\
\hline
\end{tabular}

Dry biomass of litter layer decreased in the poor forests and increased in the medium forest and the rich forests: ranging from: $0.81-6.27$ tones/ha for Nam Mau commune; $1.96-5.36$ tones/ha for Quang Khe commune, 1.13 - 5.90 tones/ha for Nam Cuong and Hoang Tri communes (table 8).

Table 8. Litter layer dry Biomass stock in standard plots of communes

\begin{tabular}{|c|c|c|c|c|c|c|c|c|c|c|c|c|c|c|c|c|c|c|}
\hline I & \multicolumn{6}{|c|}{ Poor and rehabilitated forest in Nam Mau } & \multicolumn{6}{|c|}{ Medium forest in Nam Mau } & \multicolumn{6}{|c|}{ Rich forest in Nam Mau } \\
\hline $\begin{array}{l}\text { Standard } \\
\text { plots }\end{array}$ & 1NM & 2NM & 3NM & $4 \mathrm{NM}$ & 5NM & Average & 6NM & 7NM & $8 \mathrm{NM}$ & 9NM & 10NM & Average & 11NM & $12 \mathrm{NM}$ & 13NM & $14 \mathrm{NM}$ & $15 \mathrm{NM}$ & Average \\
\hline $\begin{array}{c}\text { Dry } \\
\text { biomass } \\
\text { (tones/ha) }\end{array}$ & 2.18 & 0.81 & 1.52 & 2.42 & 2.83 & 1.95 & 6.14 & 2.70 & 2.82 & 4.41 & 4.26 & $\begin{array}{c}4.06 \\
\pm \\
1,41\end{array}$ & 3.00 & 4.44 & 3.51 & 6.27 & 5.52 & $\begin{array}{c}4.55 \\
\pm \\
1.36\end{array}$ \\
\hline II & \multicolumn{6}{|c|}{ Poor and rehabilitated forest in Quang Khe } & \multicolumn{12}{|c|}{ Medium forest in Quang Khe } \\
\hline $\begin{array}{l}\text { Standard } \\
\text { plots }\end{array}$ & $1 \mathrm{QK}$ & $2 \mathrm{QK}$ & 3QK & $4 \mathrm{QKK}$ & $5 Q \mathrm{QK}$ & Average & $6 \mathrm{QK}$ & $7 Q \mathrm{~K}$ & $8 Q K$ & 9QK & $10 Q K$ & $11 \mathrm{QK}$ & $12 \mathrm{QK}$ & $13 Q \mathrm{~K}$ & $14 Q \mathrm{~K}$ & $15 Q K$ & \multicolumn{2}{|c|}{ Average } \\
\hline $\begin{array}{c}\text { Dry } \\
\text { biomass } \\
\text { (tones/ha) }\end{array}$ & 2.35 & 2.56 & 1.96 & 3.80 & 2.71 & $\begin{array}{c}2.68 \\
\pm \\
0.96 \\
\end{array}$ & 4.65 & 2.94 & 4.67 & 3.90 & 5.36 & 3.71 & 2.79 & 4.00 & 4.69 & 5.33 & \multicolumn{2}{|c|}{$\begin{array}{c}4.20 \\
\pm \\
0.89\end{array}$} \\
\hline III & & & & & & & \multicolumn{12}{|c|}{ Medium forest in Hoang Tri } \\
\hline $\begin{array}{l}\text { Standard } \\
\text { plots }\end{array}$ & & & & & & & HT1 & HT2 & HT3 & HT4 & HT5 & HT6 & HT7 & HT8 & HT9 & HT10 & \multicolumn{2}{|c|}{ Average } \\
\hline $\begin{array}{c}\text { Dry } \\
\text { biomass } \\
\text { (tones/ha) }\end{array}$ & - & - & - & - & - & - & 1.875 & 1.885 & 1.092 & 0.545 & 1.875 & 1.353 & 1.884 & 1.025 & 1.387 & 1.846 & \multicolumn{2}{|c|}{$\begin{array}{c}1.387 \\
\pm \\
0.46\end{array}$} \\
\hline IV & \multicolumn{6}{|c|}{ Poor and rehabilitated forest in Nam Cuong } & & & & & & & & & & & & \\
\hline $\begin{array}{l}\text { Standand } \\
\text { pilots }\end{array}$ & INC & 2NC & $3 \mathrm{NC}$ & 4NC & 5NC & Average & & & & & & & & & & & & \\
\hline $\begin{array}{c}\text { Dry } \\
\text { biomass } \\
\text { (tones/ha) }\end{array}$ & 2.52 & 1.13 & 1.82 & 1.92 & 3.14 & $\begin{array}{c}2.11 \\
\pm \\
076\end{array}$ & - & - & - & - & - & - & - & - & - & - & - & - \\
\hline
\end{tabular}

Using Analyzer CHN 2000 to analysis the carbon stock of the litter layer and shrub layer, we were able to identify the accumulated carbon stock in these two layers (Table 9). 
Table 9. Carbon stock of the shrub and litter layer in the study location

\begin{tabular}{|c|c|c|c|c|c|c|c|c|c|c|c|c|c|c|c|c|c|c|}
\hline \multirow{2}{*}{$\begin{array}{c}\text { Forest types } \\
\text { Standard plots }\end{array}$} & \multicolumn{6}{|c|}{ Poor, rehabilitated forest in Nam Mau } & \multicolumn{6}{|c|}{ Medium forest in Nam Mau } & \multicolumn{6}{|c|}{ Rich forest in Nam Mau } \\
\hline & $1 \mathrm{NM}$ & 2NM & $3 N M$ & $4 N M$ & $5 \mathrm{NM}$ & average & $6 \mathrm{NM}$ & 7NM & $8 \mathrm{NM}$ & 9NM & $10 \mathrm{NM}$ & average & $11 N M$ & $12 \mathrm{NM}$ & $13 \mathrm{NM}$ & $14 \mathrm{NM}$ & $15 \mathrm{NM}$ & average \\
\hline $\begin{array}{l}\text { Shrub layer carbon } \\
\text { stock (tones/ha) }\end{array}$ & 2.05 & 0.97 & 0.70 & 1.95 & 1.77 & $\begin{array}{l}1.49 \pm \\
0.612\end{array}$ & 2.122 & 0.422 & 0.509 & 0.746 & 0.935 & $\begin{array}{l}0.95 \pm \\
0.687\end{array}$ & 0.598 & 0.404 & 0.823 & 0.284 & 0.622 & $\begin{array}{c}\mathbf{0 . 5 4 6 \pm} \\
0.209\end{array}$ \\
\hline $\begin{array}{l}\text { Litter layer carbon } \\
\text { stock (tones/ha) }\end{array}$ & 0.99 & 0.36 & 0.57 & 1.04 & 1.19 & $\begin{array}{l}\mathbf{0 . 8 3 \pm} \\
0.349\end{array}$ & 2.49 & 1.008 & 1.261 & 2.087 & 1.707 & $\begin{array}{l}1.708 \pm \\
0.601\end{array}$ & 1.386 & 1.876 & 1.379 & 2.364 & 2.514 & $\begin{array}{c}1.904 \pm \\
0.531\end{array}$ \\
\hline Forest types & \multicolumn{6}{|c|}{ Poor, rehabilitated forest in Quang Khe } & \multicolumn{12}{|c|}{ Average forest in Quang Khe } \\
\hline Standard plots & $10 \mathrm{~K}$ & $2 \mathrm{QK}$ & $3 Q \mathrm{~K}$ & 4QK & $5 Q \mathrm{~K}$ & average & $6 \mathrm{QK}$ & $7 Q \mathrm{~K}$ & $80 \mathrm{~K}$ & $9 Q \mathrm{~K}$ & $10 \mathrm{KK}$ & $11 \mathrm{QK}$ & $12 \mathrm{QK}$ & $130 \mathrm{~K}$ & $140 \mathrm{~K}$ & 15QK & \multicolumn{2}{|c|}{ average } \\
\hline $\begin{array}{l}\text { Shrub layer carbon } \\
\text { stock (tones/ha) }\end{array}$ & 2.37 & 1.43 & 0.96 & 1.87 & 1.66 & $\begin{array}{l}1.658 \pm \\
0.522\end{array}$ & 0.808 & 0.47 & 1.221 & 0.603 & 0.762 & 0.715 & 0.437 & 0.605 & 0.665 & 1.108 & \multicolumn{2}{|c|}{$\begin{array}{c}0.706 \pm \\
0.248\end{array}$} \\
\hline $\begin{array}{l}\text { Litter layer carbon } \\
\text { stock (tones/ha) }\end{array}$ & 0.63 & 0.94 & 0.64 & 1.46 & 1.12 & $\begin{array}{l}0.957 \pm \\
0.349\end{array}$ & 1.68 & 1.128 & 1.973 & 1.503 & 2.226 & 1.487 & 1.172 & 1.636 & 1.935 & 2.271 & \multicolumn{2}{|c|}{$\begin{array}{c}1.701 \pm \\
0.421\end{array}$} \\
\hline Forest types & \multicolumn{6}{|c|}{ Poor, rehabilitated forest in Nam Cuong } & \multicolumn{12}{|c|}{ Average forest in Hoang Tri } \\
\hline Standard plots & $1 \mathrm{NC}$ & $2 N C$ & $3 N C$ & 4NC & $5 N C$ & average & $1 \mathrm{HT}$ & $2 \mathrm{HT}$ & 3HT & $4 \mathrm{HT}$ & $5 \mathrm{HT}$ & $6 \mathrm{HT}$ & $7 \mathrm{HT}$ & $8 \mathrm{HT}$ & 9HT & $10 \mathrm{HT}$ & \multicolumn{2}{|c|}{ average } \\
\hline $\begin{array}{l}\text { Shrub layer carbon } \\
\text { stock (tones/ha) }\end{array}$ & - & - & - & - & - & & 1.248 & 0.512 & 0.85 & 1.166 & 0,462 & 0.39 & 1.007 & 1.215 & 0.252 & 1.083 & \multicolumn{2}{|c|}{$\begin{array}{l}\mathbf{0 . 8 1 8} \pm \\
0.436\end{array}$} \\
\hline $\begin{array}{l}\text { Litter layer carbon } \\
\text { stock (tones/ha) }\end{array}$ & - & - & - & - & - & & 0.976 & 1.875 & 1.885 & 1.092 & 0.545 & 1.353 & 1.884 & 1.025 & 1.387 & 1.846 & \multicolumn{2}{|c|}{$\begin{array}{l}1.387 \pm \\
0.363\end{array}$} \\
\hline $\begin{array}{l}\text { Shrub layer carbon } \\
\text { stock (tones/ha) }\end{array}$ & 1.34 & 0.65 & 0.66 & 1.03 & 1.48 & $\begin{array}{l}1.03 \pm \\
0.38\end{array}$ & - & - & - & - & - & & - & - & - & - & - & \\
\hline $\begin{array}{l}\text { Litter layer carbon } \\
\text { stock (tones/ha) }\end{array}$ & 1.04 & 0.43 & 0.73 & 0.77 & 1.18 & $\begin{array}{l}\mathbf{0 8 3 \pm} \\
0.292\end{array}$ & - & - & - & - & - & & - & - & - & - & - & \\
\hline
\end{tabular}


Table 10. The average carbon stock of the shrub and litter in the study location

\begin{tabular}{ccccc}
\hline Forest types & Unit & $\begin{array}{c}\text { Poor, rehabilitated } \\
\text { forest }\end{array}$ & Medium forest & Rich forest \\
\hline $\begin{array}{c}\text { Shrub carbon stock } \\
\text { in the plots }\end{array}$ & tones/ha & 1.39 & 0.779 & 0.546 \\
$\begin{array}{c}\text { Litter carbon stock } \\
\text { in the plots }\end{array}$ & tones/ha & 0.87 & 1.544 & 1.904 \\
\hline
\end{tabular}

Average carbon stock of the shrub decreased gradually from the poor, rehabilitated forest to the medium forest and the rich forest in Nam Mau commune with 1.49 tones/ha, 0.97tones/ha, 0.55 tones/ha, respectively. This data was 1.66 tones/ha for the poor, rehabilitated forest and 0.74 tones/ha for the medium forest in the Quang Khe commune. This reflected the existing situation in the rich forest. The shrub often did not develop as expected may be due to lack of sunlight.

However, in the same forest types, there were no rules in changing of carbon stock between communes. For the poor forest, the shrub average carbon stock achieved 1.66 tones/ha as the biggest in Quang Khe commune, 1.488 tones/ha as second in Nam Mau commune and 1.031 tones/ha as the lowest in Nam Cuong commune. For the medium forest, the shrub average carbon stock achieved 0.95 tones/ha as the biggest in Nam Mau commune, 0.82 tones/ha as second in Hoang Tri, 0.74 tones/ha as the lowest in Quang Khe commune.

The carbon stock of the litter layer tended to be opposit to the shrub layer, the carbon stock increased gradually from the poor forest to rich forest, gained averagely 0.83 tones/ha in the poor forest in Nam Cuong commune to 1.904 tones/ha in rich forest in Nam Mau commune, and achieved 2.514 tones/ha as the maximum value in the surveyed plot 15NM.

The above results showed that the litter and shrub carbon stockwas much littler than the aboveground carbon. The carbon stock of the shrub accounted for $0.2-4.2 \%$ of the aboveground carbon, while the carbon stock for the litter reached from 0.7 to $2.6 \%$ of the aboveground carbon. This depended on the kind and state of forests. This result is similar to the report of Syafinie (2015) in estimation of aboveground biomass and carbon stock in logged-over lowland tropical forest in Malaysia, the proportion of litter carbon stock was $0,76 \%$ of the aboveground carbon (Syafinie and Ainuddin, 2015). Some researchers estimated the litter carbon pool accounts for $5 \%(43 \mathrm{Pg})$ of carbon stocks for all forest ecosystem in the world (Pan et al., 2011). In contrast, the specific model (Service, Smith and Heath, 2002) was used in the 1990-2012 US national greenhouse gas inventory predicted litter carbon at $11.7 \%$. Therefore, there is a difference in the gap between methods to estimate Carbon stock and kinds of forest and so on.

Studies on the stock of carbon in shrub and litter layers are quite limited because the carbon stock is not large, the forecast of carbon fluctuations in these two layers is also complicated, so most of the studies on forest carbon inventories are often abandoned through the carbon stock in these 2 layer specially the researches use remote-sensing technology (Gibbs et al., 2007; Prasada et al., 2016).

\subsection{Total carbon sequestration in the entire forest area}

From the above results, we identified the accumulated carbon stock in the Ba Be National Park through 3 layers: woody stem, shrub and litter in 3 types of forest: the poor forest, rehabilitated forest, average forest and rich forest. in which, the average carbon stock of the rich forest, the medium forest and the poor, rehabilitated forest achevied 273.17 tones/ha, 113.69 tones/ha and 35,68 tones/ha, respectively. The results are shown in Figure 5. 


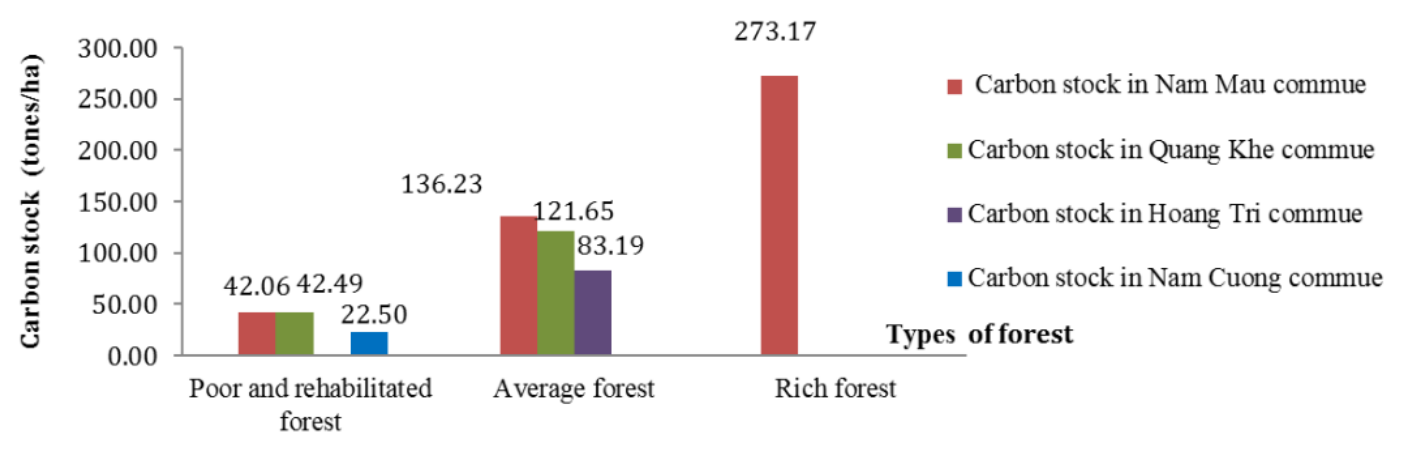

Figure 5. Carbon stock on the ground at the plots in the surveyed communes

According to the Management Board, the current status of forest area at the National Park is shown in Table 11.

Table 11. Forest area status of Ba Be National Park

\begin{tabular}{|l|l|r|r|r|r|r|r|}
\hline Types of Forest & Unit & Total & Nam Mau & Quang Khe & Hoang Tri & \multicolumn{1}{c|}{$\begin{array}{c}\text { Nam } \\
\text { Cuong }\end{array}$} & $\begin{array}{c}\text { Other } \\
\text { commues }\end{array}$ \\
\hline Rich & $\mathrm{Ha}$ & 2234.3 & 2180.4 & 0 & 0 & 0 & 53.9 \\
\hline Average & $\mathrm{Ha}$ & $2,566.1$ & 1780.1 & 493.1 & 43.7 & 0 & 249.2 \\
\hline $\begin{array}{l}\text { Poor and } \\
\text { rehabilitated }\end{array}$ & $\mathrm{Ha}$ & 622.6 & 240.2 & 273.9 & 0 & 21.8 & 86.7 \\
\hline
\end{tabular}

(Source: Ba Be National Park Management Board, 2018)

From figure 5 and Table 11, the research team identified the carbon stock in the Ba Be National Park in the rich forest is $610,342.48$ tones, the medium forest is $284,537.32$ tones and the poor forest, restored forest is $21,736.15$ tones.

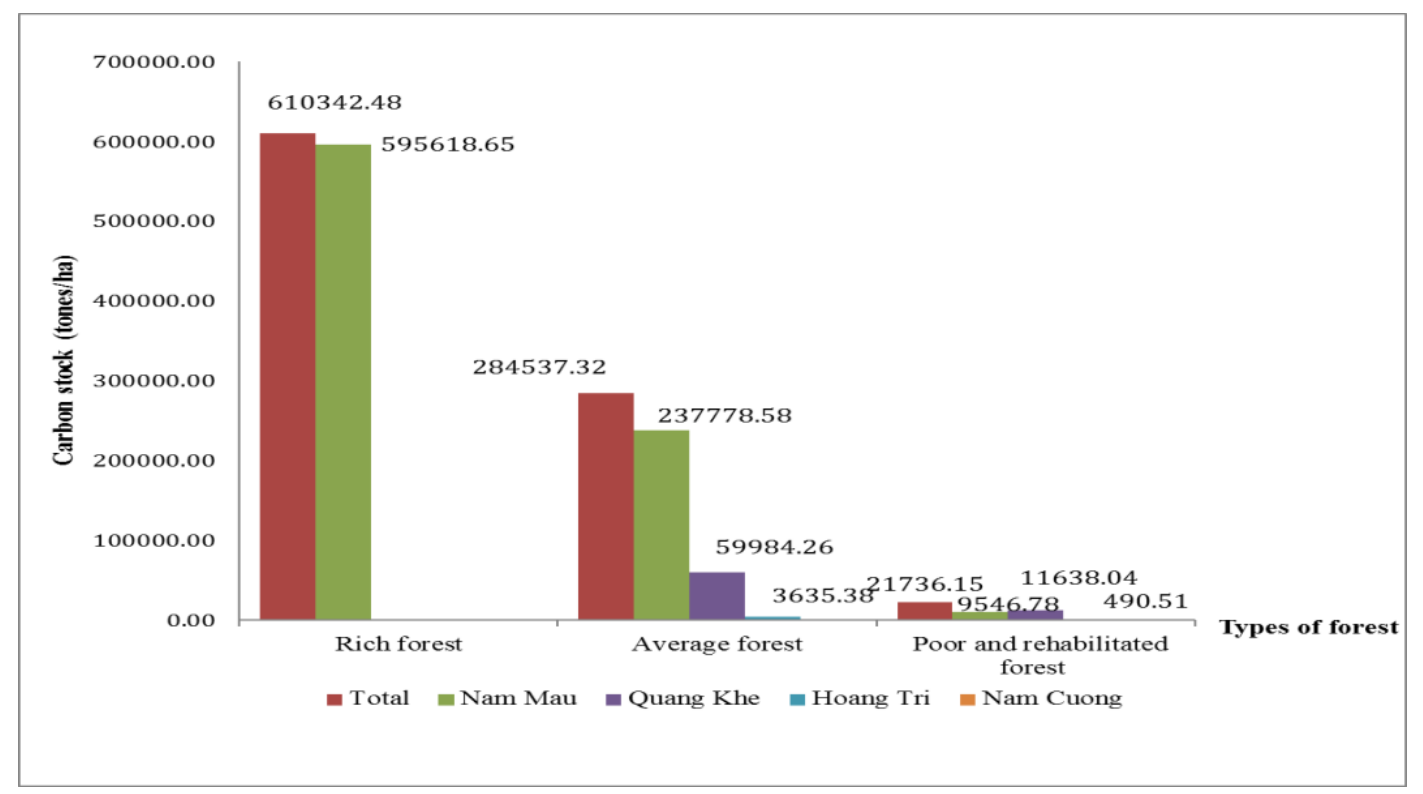

Figure 6. Carbon stocks in the Ba Be National Park 
According to ICRAF in combined with the Forest Inventory and Planning Institute (2010), the annual forest growth rate in Bac Kan province is $1.8 \%$ per year. Thus, every year, the accumulated carbon stock in three kinds of forests, including rich, medium, and poor, rehabilitated forest in $\mathrm{Ba}$ Be National Park will increase by about 16499.087 tones of carbon per year. This may contribute to reduction of greenhouse gas emissions, leading to improvement of microclimate quality in the region.

The annual estimation of forest carbon stock is also a scientific basis for buyers of the carbon sequestration service to pay well the forest growers and protecters, ensuring transparency and fairness in the payment of forest environmental services and completing the payment mechanism for forest environmental services in Bac Kan province. Stakeholders can know the effectiveness of forest management and protection through annual monitoring of forest carbon stocks.

\section{Conclusions}

The collected results, investigating and analyzing samples at 45 standard plot for 3 forest states: the rich forest, the medium forest, the poor forest and rehabilitated forest in the Ba Be National Park, we identified that the carbon stock in the Ba Be National Park accumulates for rich forest is 273.17 tones/ha, the medium forest is 136.23 tones/ha and the poor, restored forest is 42.06 tones/ ha. It means that the carbon sequestration of the rich forest were the largest. Our results will serve as a scientific basis for developing a mechanism for payment of forest carbon services in $\mathrm{Ba} B e$ National Park in particular, Bac Kan province in general and other localities with similar conditions.

\section{Acknowledgement}

The authors would like to thank BaBe national park management Board for their help during the field trip. Special thanks to Prof. Dr. Filip Bravo and Dr. Juan Carlos Arranz, Valladolid University, Spain, Prof. Dr. Vu Van Manh, VNU University of Science, Viet Nam for their support of this study.

\section{Conflicts of Interest}

I affirm that authorshave no conflict of interest within the article. I affirm that the founding sponsors had no role in the design of the study; in the collection, analysis, or interpretation of data; in the writing of the manuscript, and in the decision to publish the results.

\section{References}

Abeydeera, L. H. U. W., Mesthrige, J. W. and Samarasinghalage, T. I. (2019). Global research on carbon emissions: A scientometric review. Sustainability (Switzerland), 11(14), 1-25. doi: https://doi.org/10.3390/su11143972

Ba Be National Park Management Board (2013) Sustainable forest conservation and development planning of Ba Be National Park, Bac Kan province, Viet Nam, period 2012 - 2020. Bac Kan.

Brown, S. (1997). Estimating biomass and biomass change of tropical forests: a Primer. in $F A O$ Forestry paper. FAO Forestry paper, p. 134.

Chaturvedi, R. K., Singh, J. S. and Raghubanshi, A. S. (2012). Biomass Estimation of Dry Tropical Woody Species at Juvenile Stage. The Scientific World Journal, p. 5. doi: http://dx.doi.org/10.1100/2012/790219

Chaturvedi, R.K., Raghubanshi, A. S. (2015). Allometric models for accurate estimation of aboveground biomass of teak in tropical dry forests of India. Forest Science, 5(28), 938-949.doi: https://doi.org/10.5849/forsci.14-190

Chaturvedi, R. K., Raghubanshi, A. S. and Singh, J. S. (2010). Non-destructive estimation of tree biomass by using wood specific gravity in the estimator. National Academy Science Letters, 33(5-6), 133-138.

Chaturvedi, R. K., Singh, J. S. and Raghubanshi, A. S. (2011). Carbon density and accumulation in 
woody species of tropical dry forest in India. Forest Ecology and Management, 262(8), 15761588. doi: http://dx.doi.org/10.1016/j.foreco.2011.07.006 .

Chaturvedi R.K and Raghubanshi, A. S. (2013). Aboveground biomass estimation of small diameter woody species of tropical dry forest. Search worldwide, life-sciences literature, 44(4), 105-109. doi: https://doi.org/10.1007/s11056-012-9359-z

Chave, J., Andalo, C., Brown, S., Cairns, M. A., Chambers, J. Q., Eamus, D., ... \& Lescure, J. P. (2005). Tree allometry and improved estimation of carbon stocks and balance in tropical forests. Oecologia, 145(1), 87-99. doi: https://doi.org/10.1007/s00442-005-0100-x

Dixon, R. K., Solomon, A. M., Brown, S., Houghton, R. A., Trexier, M. C., \& Wisniewski, J. (1994). Carbon pools and flux of global forest ecosystems. Science, 263(5144), 185-190. doi: https://doi.org/10.1126/science.263.5144.185

Ekoungoulou, R. Liu, X., Ifo, S. A., Loumeto, J. J., \& Folega, F. (2014). Carbon stock estimation in secondary forest and gallery forest of Congo using allometric equations. International Journal of Scientific and Technology Research, 3(3), 465-474

Environmental Analysis Unit: Defra. (2016). DEFRA's Payment for Ecosystem Services Pilot Projects 2012-2015', (December), p. 20.

Eroglu S., Toprak S., Urgan O, MD, Ozge E. Onur, MD, Arzu Denizbasi, MD, Haldun Akoglu, MD, Cigdem Ozpolat, MD, Ebru Akoglu, M. (2012) 'No Title No Title', Saudi Med J, 33, 3-8. doi: https://doi.org/10.1073/pnas.0703993104

Gibbs, H. K., Brown, S., Niles, J. O., \& Foley, J. A. (2007). Monitoring and estimating tropical forest carbon stocks: making REDD a reality. Environmental Research Letters, 2(4), 045023. doi: https://doi.org/10.1088/1748-9326/2/4/045023

Green, E. P., Mumby, P. J., Edwards, A. J., Clark, C. D., \& Ellis, A. C. (1997). Estimating leaf area index of mangroves from satellite data. Aquatic botany,58(1), 11-19. doi: https://doi.org/10.1016/S0304-3770(97)00013-2

Gunawardena, A. . (2014) Land use, land cover types in Sri Lanka using remote sensing as nondestructive sampling technique. of Agriculture, University of Peradeniya, Peradeniya, Sri Lanka.

Huy, B. and Tuan, P. (2008). Estimating CO2 sequestration in natural broad-leaved evergreen forests in Viet Nam.', UN Redd programme, Viet Nam, 32, 7-10.

IPCC. (2006). IPCC Guidelines for National Greenhouse Gas Inventories. Volume 4: Agriculture, Forestry and Other Land Use. JaPan.

Karsenty, A., Blanco, C. and Dufour, T. (2002). Instruments related to the united nations framework convention on climate change and their potential for sustainable forest management in Africa. Paris.

Keeling, C. and Whort, T. (2002). Atmospheric CO2 records from sites in the SIO air sampling network.

Lüthi, D., Le Floch, M., Bereiter, B., Blunier, T., Barnola, J. M., Siegenthaler, U., ... \& Stocker, T. F. (2008). High-resolution carbon dioxide concentration record $650,000-800,000$ years before present. Nature, 453(7193), 379-382.doi: https://doi.org/10.1038/nature06949

NOAA. (2008). Annual Greenhouse Gas Index 2008- New data show unrelenting rise in carbon dioxide and other greenhouse gases.

NOAA. (2019). Carbon dioxide levels in atmosphere hit record high in May, 2019.

Omasa, K., Qiu, G. Y., Watanuki, K., Yoshimi, K., \& Akiyama, Y. (2003). Accurate estimation of forest carbon stocks by 3-D remote sensing of individual trees. Environmental Science \& Technology, 37(6), 1198-1201. doi: https://doi.org/10.1021/es0259887

Phuong, V. T. (2012). Forests and Allometric Equation Development for Biomass Estimation in Vietnam, (June).

Prasad, O. P., Hussin, Y. A., Weir, M. J., \& Karna, Y. K. (2016). Derivation of forest inventory parameters for carbon estimation using terrestrial LiDAR, International Archives of the Photogrammetry, Remote Sensing and Spatial Information Sciences - ISPRS Archives, 41(i), 677- 
684. doi: https://doi.org/10.5194/isprsarchives-XLI-B8-677-2016

Syafinie Abdul Majid and Ainuddin, N. A. (2015). Aboveground biomass and carbon stock estimation in logged-over lowland tropical forest in Malaysia. International Journal of Agricultural, Forestry \& Plantation., 1, 1-14.

UN- REDD VietNam. (2012) Guidelines on Destructive Measurement for Forest Biomass Estimation.

UN-REDD Programe Viet Nam (2012) Part B-2 Tree allometric equations in Evergreen broadleaf and Bamboo forests in the North East region, Viet Nam. Ha Nôi.

UNFCCC. (2007). Fact sheet: Climate change science.

Vu, T. D., Takeuchi, W. and Van, N. A. (2014). Carbon Stock Calculating and Forest Change Assessment Toward REDD+ Activities for The Mangrove Forest in Vietnam. Transactions of the Japan Society for Aeronautical and Space Sciences, Aerospace Technology Japan, 12(29), 2331. doi: https://doi.org/10.2322/tastj.12.pn_23

Walker, S. M., Murray, L. and Tepe, T. (2015). Allometric Equation Evaluation Guidance Document', (June), p. 75.

Wilson, N. (2010). Biomass and regeneration of mangrove vegetation in Kien Giang Province, Vietnam.

Yen, V. T., Nguyen, H. K. L., Nguyen, B. N., \& Le, Q. T. (2016). Study on biomass and carbon stock of woody floor at several forests in Bach Ma national park, Thua Thien Hue province. Journal of Vietnamese Environment, 8(2), 291-297. doi: https://doi.org/10.13141/jve.vol8.no2.pp88-94 